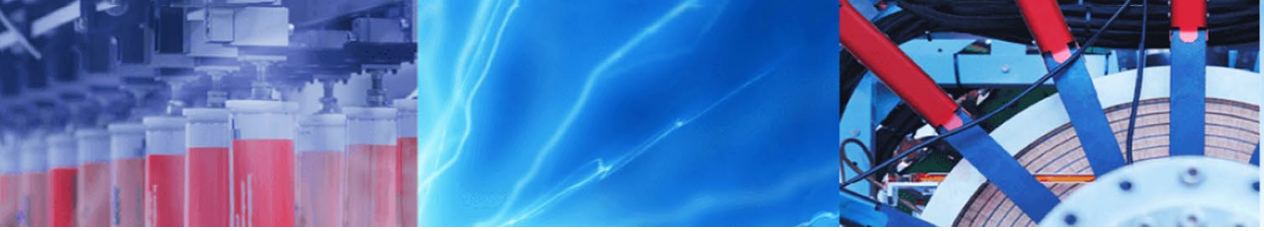

Research Article

\title{
Synthesis and characterization of comb-type graft copolymers by redox polymerization and "click" chemistry method
}

\author{
Bedrettin Savaş ${ }^{1} \cdot$ Temel Öztürk $^{2}$ (D) Ergül Meyvacı $^{2} \cdot$ Baki Hazer $^{3,4}$
}

Received: 21 August 2019 / Accepted: 6 January 2020 / Published online: 10 January 2020

(c) Springer Nature Switzerland AG 2020

\begin{abstract}
The synthesis of poly(epichlorohydrin-g-methyl methacrylate) [poly(ECH-g-MMA)] comb-type graft copolymers were carried out by use of a "click" chemistry to graft terminally propargyl poly(methyl methacrylate) (PMMA-propargyl) to poly(epichlorohydrin) azido ( $\mathrm{PECH}-\mathrm{N}_{3}$ ). For this purpose, $\mathrm{PECH}-\mathrm{N}_{3}$ was synthesized by using poly(epichlorohydrin) and sodium azide. PMMA-propargyl was obtained by reaction of methyl methacrylate and propargyl alcohol via redox polymerization technique. By using $\mathrm{PECH}-\mathrm{N}_{3}$ and PMMA-propargyl, the comb-type graft copolymers were obtained. Characterization of the modified homopolymers and the comb-type graft copolymers was performed by using FT-IR, ${ }^{1} \mathrm{H}-\mathrm{NMR}, \mathrm{SEM}, \mathrm{GPC}$, and elemental analysis techniques. Thermal transitions and degradation features of the comb-type graft copolymers were investigated by using DSC and TGA methods. Spectroscopic and thermal analyses revealed that both group modifications and coupling reactions were successfully achieved.
\end{abstract}

Keywords "Click" chemistry · Redox polymerization · Comb-type graft copolymer · Poly(epichlorohydrin) · Poly(methyl methacrylate)

\section{Introduction}

After Sharpless et al. [1] described "click" chemistry method in 2001, applications of the methods have been widely studied [2-17]. Polyepichlorohydrin (PECH) is present in many syntheses of copolymers [18-22]. Poly(methyl methacrylate) (PMMA) is frequently used in sheet form as an alternative to glass. Copolymers have important interest for their mechanical properties and practical applications [9]. Block or graft copolymers are used in scientific applications and research [23-31]. One of the most important of these regularly branched polymers is the brush type copolymers. Brush type polymers usually consist of three categories considering the type and number of side chain, and the formation of framework. The first group includes one linear branch of homopolymer or diblock copolymer as the side chains deployed on each unit of the polymer backbone created by homopolymerization of one monomer [32].

This paper demonstrates the synthesis of poly(epichlorohydrin-g-methyl methacrylate) [poly(ECHg-MMA)] comb-type graft copolymers by using "click" chemistry. In our previous work, we synthesized poly(epichlorohydrin) azido $\left(\mathrm{PECH}-\mathrm{N}_{3}\right)$ [14]. Terminally propargyl poly(methyl methacrylate) (PMMA-propargyl) was obtained by reaction of MMA with propargyl alcohol via redox polymerization technique as shown the literature [33]. In this study, the synthesis of poly(ECH-gMMA) comb-type graft copolymers obtained by "click" chemistry reaction of $\mathrm{PECH}-\mathrm{N}_{3}$ and PMMA-propargyl were introduced. Characterization of the comb-type graft

$\triangle$ Temel Öztürk, temel.ozturk@giresun.edu.tr| ${ }^{1}$ Kars Vocational School, Kafkas University, 36100 Kars, Turkey. ${ }^{2}$ Department of Chemistry, Faculty of Arts and Sciences, Giresun University, 28200 Giresun, Turkey. ${ }^{3}$ Department of Aircraft Airframe Engine Maintenance, Kapadokya University, 50420 Ürgüp, Nevşehir, Turkey. ${ }^{4}$ Department of Chemistry, Department of Nano Technology Engineering, Zonguldak Bülent Ecevit University, 67100 Zonguldak, Turkey. 
copolymers was performed by using FT-IR, ${ }^{1} \mathrm{H}-\mathrm{NMR}$, SEM, GPC, TGA, and DSC.

\section{Experimental}

\subsection{Materials}

Propargyl alcohol, $\mathrm{N}, \mathrm{N}$-dimethylformamide (DMF), nitric acid $\left(\mathrm{HNO}_{3}\right)$, sodium bicarbonate $\left(\mathrm{NaHCO}_{3}\right)$, sodium sulfate $\left(\mathrm{Na}_{2} \mathrm{SO}_{4}\right), \mathrm{PECH}$, copper(I) bromide (CuBr), sodium azide $\left(\mathrm{NaN}_{3}\right)$, and $N, N, N^{\prime}, N^{\prime}, N^{\prime \prime}$-pentamethyldiethylenetriamine (PMDETA), ammonium cerium (IV) nitrate $\left[\mathrm{Ce}\left(\mathrm{NH}_{4}\right)_{2}\left(\mathrm{NO}_{3}\right)_{6}\right]$ were received from Sigma-Aldrich. MMA and methanol were supplied by Merck. An alumina column was used to remove the inhibitor from MMA.

\subsection{Instrumentation}

${ }^{1} \mathrm{H}$-NMR spectra were recorded using Bruker Ultra Shield Plus, ultra-long hold time 400 NMR spectrometers. FT-IR spectra were detected using Jasco FT/IR 6600 FT-IR spectrometer in the range of $600-4000 \mathrm{~cm}^{-1}$. Mw, Mn, and dispersities were examined with HPLC/GPC-Shimadzu RID-10A GPC instrument with DMF mobile phase as the solvent $40{ }^{\circ} \mathrm{C}$ using Refractive Index Detector (RID-10A). Polystyrene standards: $1490 \mathrm{Da}(\mathrm{Mw}), 2500 \mathrm{Da}(\mathrm{Mw})$, $5480 \mathrm{Da}(\mathrm{Mw}), 9500 \mathrm{Da}(\mathrm{Mw}), 20,800 \mathrm{Da}(\mathrm{Mw}), 53,500 \mathrm{Da}$ (Mw) 171,000 Da (Mw), 295,900 Da (Mw), 410,000 Da $(\mathrm{Mw})$, and 566,200 of low polydispersity. Scanning Electron Microscopy (SEM) images was taken on a Zeiss EVO LS 10 electron microscope. The elemental analyses of the products were performed by a Costech ECS 4010. Thermogravimetric analysis (TGA) measurements were conducted using a Seiko II Exstar 6000 model instrument. The samples were heated at a rate of $10^{\circ} \mathrm{C} / \mathrm{min}$ from $25^{\circ} \mathrm{C}$ to $800{ }^{\circ} \mathrm{C}$ under $\mathrm{N}_{2}$. Differential scanning calorimetry (DSC) measurements were conducted at a rate of $10^{\circ} \mathrm{C} / \mathrm{min}$ from $-80^{\circ} \mathrm{C}$ to $150^{\circ} \mathrm{C}$ under $\mathrm{N}_{2}$ atmosphere using a Perkin Elmer DSC 8500 series instrument.

\subsection{Synthesis of poly(epichlorohydrin) azido (PECH- $\mathrm{N}_{3}$ )}

PECH- $\mathrm{N}_{3}$ were obtained as in our previous work [14]. Briefly, $1.43 \times 10^{-5} \mathrm{~mol}$ of PECH, $3.08 \times 10^{-2} \mathrm{~mol}_{\text {of }} \mathrm{NaN}_{3}$, and $100 \mathrm{~mL}$ of DMF (as the solvent) were placed into a $250 \mathrm{~mL}$ flask. The flask was immersed in an oil bath fixed at $70{ }^{\circ} \mathrm{C}$ on a magnetic stir plate, and $\mathrm{N}_{2}$ gas was introduced by injection with a needle. After $48 \mathrm{~h}$, the flask was opened, and the contents were filtered. The sample washed with $30 \mathrm{wt} \% \mathrm{NaHCO}_{3}$ then dried over $\mathrm{Na}_{2} \mathrm{SO}_{4}$ to remove unreacted $\mathrm{NaN}_{3}$ and then the organic phase was separated. The solvent was evaporated by using a rotary evaporator. The residue was drained into excess methanol to separate PECH- $\mathrm{N}_{3}$. After decantation, the product was dried at $25^{\circ} \mathrm{C}$ under vacuum for two days. PECH-N yield was defined gravimetrically. The gravimetric conversion obtained from the weight of $\mathrm{PECH}-\mathrm{N}_{3}$ was $97.0 \mathrm{wt} \%$. FT-IR spectrum of PECH-N $\mathrm{N}_{3}$ in Fig. 1 a shows the signals at $3664 \mathrm{~cm}^{-1}$ for $-\mathrm{OH}, 2920 \mathrm{~cm}^{-1}$ for aliphatic $-\mathrm{CH},-\mathrm{CH}_{2}$, $2094 \mathrm{~cm}^{-1}$ for $-\mathrm{N}_{3}$ and $1084 \mathrm{~cm}^{-1}$ for $-\mathrm{OC}$. The ${ }^{1} \mathrm{H}-\mathrm{NMR}$ spectrum of $\mathrm{PECH}$ [Fig. 2a] displayed peaks at $3.7 \mathrm{ppm}$ for $-\mathrm{OCH}_{2}$ and for $-\mathrm{OCH}, 3.4 \mathrm{ppm}$ for $-\mathrm{NCH}_{2}$, and $1.7 \mathrm{ppm}$ for $-\mathrm{OH}$. Mn value of $\mathrm{PECH}-\mathrm{N}_{3}$ was $20,750 \mathrm{~g} \mathrm{~mol}^{-1}$. Dispersity value of $\mathrm{PECH}-\mathrm{N}_{3}$ was 2.78 . The result of the elemental analysis of $\mathrm{PECH}-\mathrm{N}_{3}$ shows $24.36 \mathrm{~N}$ wt $\%$.

\subsection{Synthesis of terminally propargyl poly(methyl methacrylate) (PMMA-propargyl) by redox polymerization}

PMMA-propargyl were obtained as the literature [33]. Briefly, $9.99 \times 10^{-2} \mathrm{~mol}$ of MMA, $3.21 \times 10^{-2} \mathrm{~mol}$ of propargyl alcohol, $2.92 \times 10^{-3} \mathrm{~mol}$ of ammonium cerium (IV) nitrate, and $30 \mathrm{~mL}$ of 1 molar nitric acid solution were placed into a $250 \mathrm{~mL}$ flask around closed with aluminum

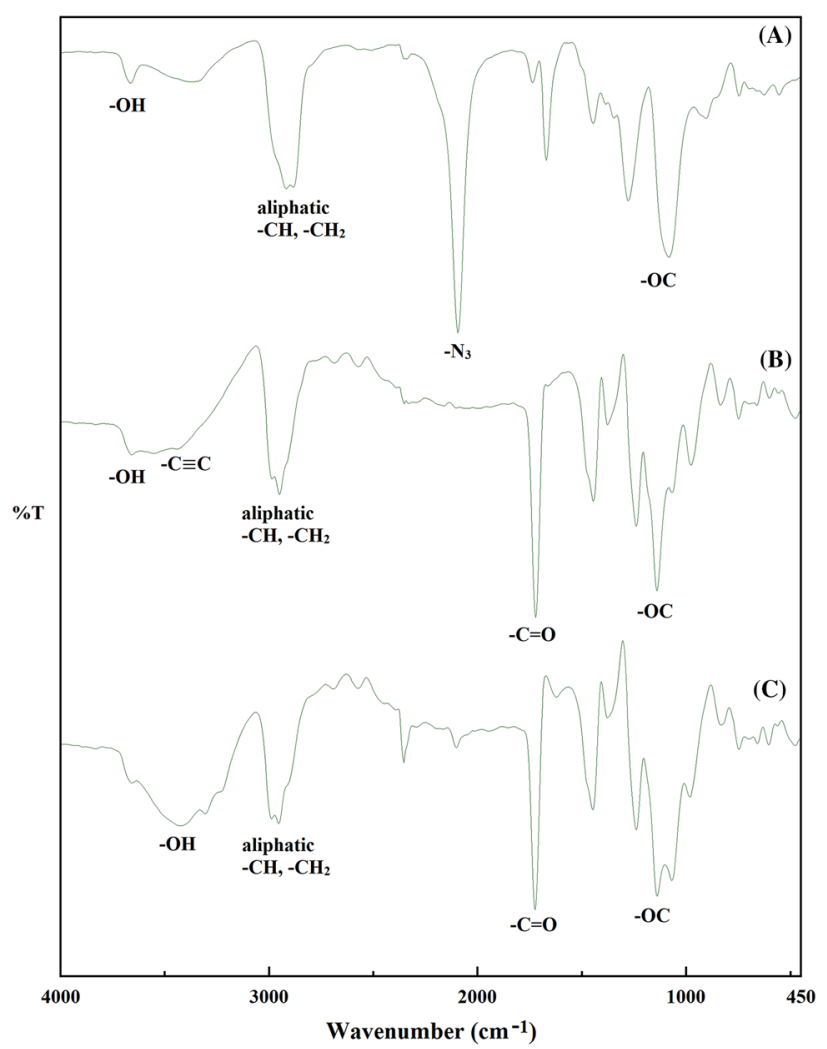

Fig. 1 FT-IR spectrum of a PECH-N ${ }_{3}$; b PMMA-propargyl; c poly (ECH-g-MMA) comb-type graft copolymer (R2M2-3 in Table 1) 

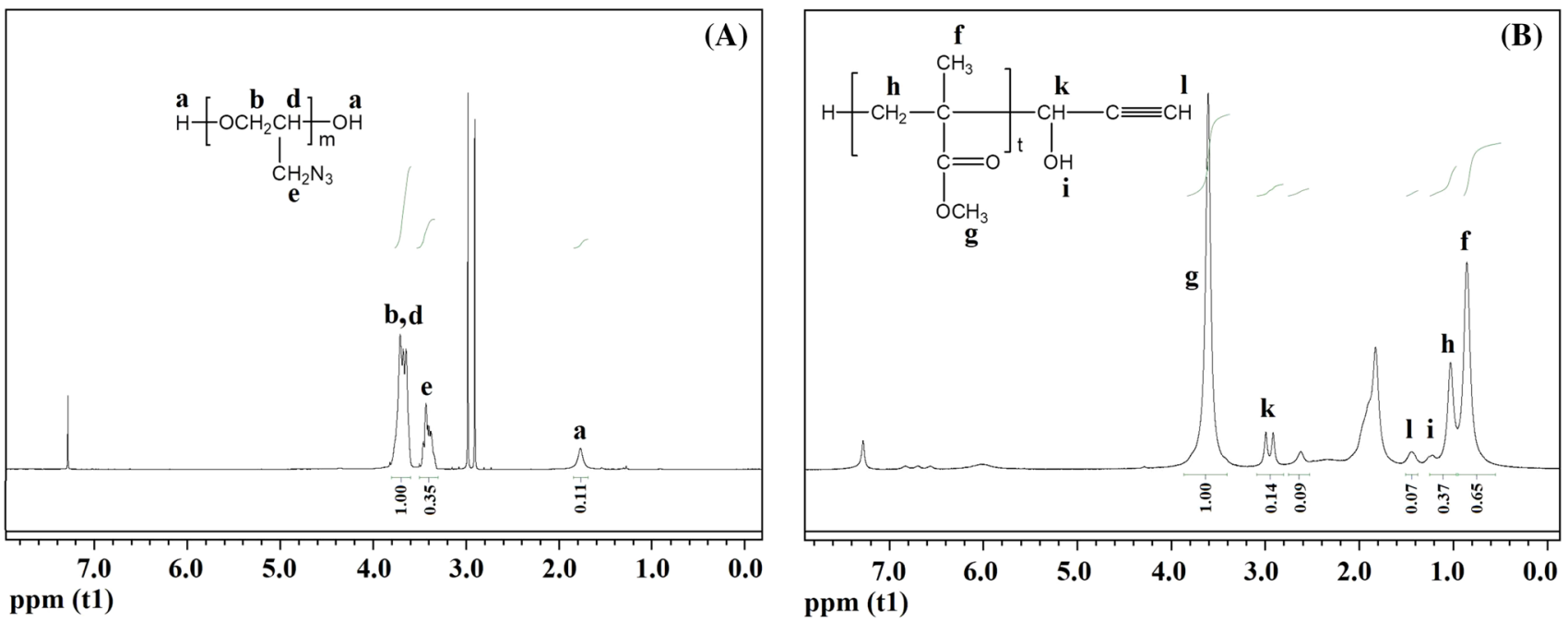

$\operatorname{ppm}(\mathbf{t} 1)$

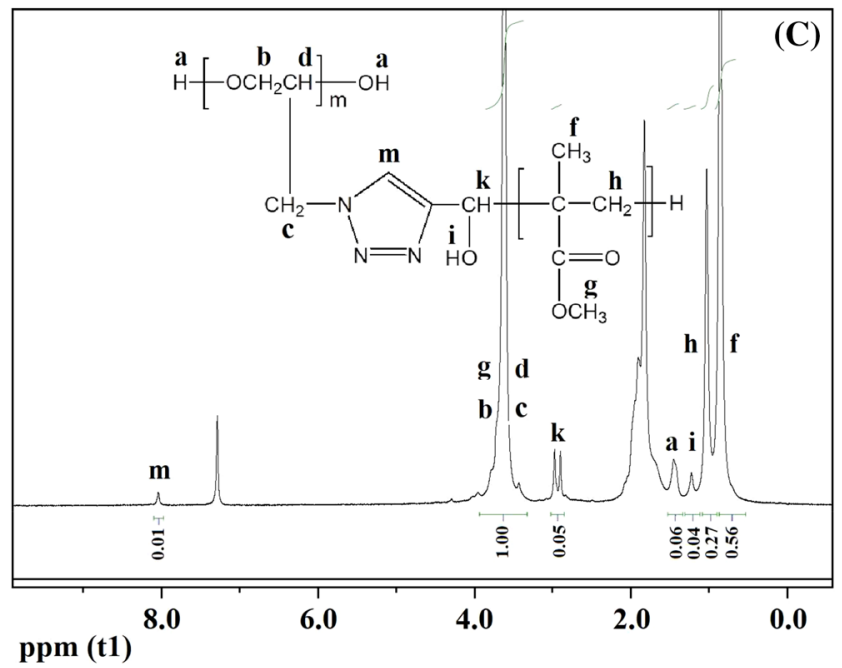

Fig. 2. ${ }^{1} \mathrm{H}-\mathrm{NMR}$ spectra of a PECH-N ${ }_{3}$; b PMMA-propargyl; c poly (ECH-g-MMA) comb-type graft copolymer (R2M2-3 in Table 1)

foil followed by $\mathrm{N}_{2}$ gas inert atmosphere. The mixture was stirred at $30^{\circ} \mathrm{C}$ for $24 \mathrm{~h}$. The resulting product was precipitated in methanol. After decantation, the product was dried at $25^{\circ} \mathrm{C}$ under vacuum for two days. The gravimetric conversion was $8.0 \mathrm{wt} \%$. FT-IR spectrum of PMMA-propargyl in Fig. $1 \mathrm{~b}$ shows the signals at $3660 \mathrm{~cm}^{-1}$ for $-\mathrm{OH}, 2950 \mathrm{~cm}^{-1}$ for aliphatic $-\mathrm{CH},-\mathrm{CH}_{2}$, $3350 \mathrm{~cm}^{-1}$ for $-\mathrm{C} \equiv \mathrm{C}, 1724 \mathrm{~cm}^{-1}$ for $-\mathrm{C}=\mathrm{O}$, and $1142 \mathrm{~cm}^{-1}$ for -OC. The ${ }^{1} \mathrm{H}-\mathrm{NMR}$ spectrum PMMA-propargyl in Fig. $2 \mathrm{~b}$ displayed peaks at $3.6 \mathrm{ppm}$ for $-\mathrm{OCH}_{3}, 3.0 \mathrm{ppm}$ for-OCH linked PMMA unit, $1.2 \mathrm{ppm}$ for $-\mathrm{OH}, 1.1 \mathrm{ppm}$ for $-\mathrm{C} \equiv \mathrm{CH}, 1.0 \mathrm{ppm}$ for aliphatic $-\mathrm{CH}_{2}$, and $0.9 \mathrm{ppm}$ for aliphatic $-\mathrm{CH}_{3}$. Mn value of PMMA-propargyl was $13,322 \mathrm{~g} \mathrm{~mol}^{-1}$. Dispersity value of PMMA-propargyl was 1.11 .

\subsection{Synthesis of poly(epichlorohydrin-g-methyl methacrylate) comb-type graft copolymers by "click" chemistry}

Poly(ECH-g-MMA) comb-type graft copolymers was synthesized by "click" chemistry in this study. The amounts of chemicals used in the copolymerization are shown in Table 1. PMMA-propargyl, PECH-N ${ }_{3}, \mathrm{CuBr}$, PMDETA, and DMF were put separately into a Schlenk tube followed by nitrogen gas for two min. The tube was put in an oil bath at $35^{\circ} \mathrm{C}$ on a magnetic stirrer. After $48 \mathrm{~h}$, the flask contents were filtered. The mixture was drained into methanol to separate precipitated poly(ECH-g-MMA) comb-type graft copolymers. Small alumina column was used to remove remaining copper catalyst from the comb-type graft 
Table 1 Synthesis of poly(ECH-g-MMA) comb-type graft copolymers by "click" chemistry

\begin{tabular}{|c|c|c|c|c|c|c|c|c|c|c|}
\hline \multirow[t]{2}{*}{ Code } & \multirow[t]{2}{*}{$\begin{array}{l}\text { PMMA-propar- } \\
\text { gyl }\left(\mathrm{mol} \times 10^{-6}\right)\end{array}$} & \multirow[t]{2}{*}{$\begin{array}{l}\mathrm{PECH}-\mathrm{N}_{3} \\
\left(\mathrm{~mol} \times 10^{-5}\right)\end{array}$} & \multirow[t]{2}{*}{$\begin{array}{l}\mathrm{CuBr} \\
\left(\mathrm{mol} \times 10^{-4}\right)\end{array}$} & \multirow[t]{2}{*}{$\begin{array}{l}\text { PMDETA } \\
\left(\mathrm{mol} \times 10^{-4}\right)\end{array}$} & \multirow[t]{2}{*}{ Yield (g) } & \multirow[t]{2}{*}{ Eff } & \multirow[t]{2}{*}{$\mathrm{Mn}, \mathrm{GPC}\left(\mathrm{g} \mathrm{mol}^{-1}\right)$} & \multirow[t]{2}{*}{$\mathrm{Mw} / \mathrm{Mn}$} & \multicolumn{2}{|c|}{$\begin{array}{l}\text { Decomp. } \\
\text { temp. }\left({ }^{\circ} \mathrm{C}\right)\end{array}$} \\
\hline & & & & & & & & & Td1 & $\mathrm{Td} 2$ \\
\hline R2M2-1 & 7.73 & 1.00 & 3.62 & 2.42 & 0.239 & 0.75 & 31,460 & 2.01 & 215 & 395 \\
\hline R2M2-2 & 7.65 & 2.08 & 5.16 & 3.52 & 0.457 & 0.78 & 25,717 & 2.10 & 227 & 415 \\
\hline $\mathrm{R} 2 \mathrm{M} 2-3$ & 8.03 & 3.18 & 6.41 & 4.90 & 0.715 & 0.80 & 39,128 & 1.97 & 230 & 414 \\
\hline R2M2-4 & 7.58 & 4.01 & 8.50 & 5.94 & 0.886 & 0.84 & 30,004 & 2.07 & 232 & 417 \\
\hline
\end{tabular}

Reaction temperature: $35^{\circ} \mathrm{C}$; polymerization time: $48 \mathrm{~h}$; DMF: $20 \mathrm{~mL}$ eff.: efficiency of "click" chemistry

copolymer. The copolymer was dried at $25^{\circ} \mathrm{C}$ for two days in vacuum oven. Vacuum dried copolymer sample was dissolved in chloroform, a good solvent for the copolymer. Methanol was added drop wise to the solution with mixing until turbidity forms, and then 1-3 $\mathrm{mL}$ methanol was added to complete the precipitation. After decantation, the dried copolymer sample was defined gravimetrically. The efficiency of click coupling was included in Table 1. There was not significant unreacted $\mathrm{PECH}-\mathrm{N}_{3}$ in poly $(\mathrm{ECH}-$ g-MMA) comb-type graft copolymer. The gravimetric conversion was between $94.87 \mathrm{wt} \%$ and $76.71 \mathrm{wt} \%$. The FT-IR spectrum of poly(ECH-g-MMA) comb-type graft copolymers in Fig. 1c shows the signals at $3425 \mathrm{~cm}^{-1}$ for $-\mathrm{OH}$, $2950 \mathrm{~cm}^{-1}$ for aliphatic $-\mathrm{CH},-\mathrm{CH}_{2}, 1724 \mathrm{~cm}^{-1}$ for $-\mathrm{C}=\mathrm{O}$, and $1138 \mathrm{~cm}^{-1}$ for $-\mathrm{OC}$. The ${ }^{1} \mathrm{H}$-NMR spectrum of the comb-type graft copolymers shown in Fig. 2c displayed peaks at $8.0 \mathrm{ppm}$ for aromatic $-\mathrm{CH}$ of triazole ring, $3.6 \mathrm{ppm}$ for $-\mathrm{OCH}_{3}$ of PMMA unit and $-\mathrm{OCH},-\mathrm{OCH}_{2}$ of $\mathrm{PECH}$ unit, $3.0 \mathrm{ppm}$ for -OCH linked PMMA unit, $1.5 \mathrm{ppm}$ for $-\mathrm{OH}$ of $\mathrm{PECH}$ unit, $1.2 \mathrm{ppm}$ for -OH linked PMMA unit, $1.0 \mathrm{ppm}$ for aliphatic $-\mathrm{CH}_{2}$ of PMMA unit, and 0.9 ppm for aliphatic $-\mathrm{CH}_{3}$ of PMMA unit.

\section{Results and discussion}

\subsection{Synthesis of PECH-N}

$\mathrm{PECH}-\mathrm{N}_{3}$ was synthesized starting from PECH. Scheme 1 (first line) includes the reaction pathway for the synthesis of PECH- $\mathrm{N}_{3}$. The observed peaks at $2.9 \mathrm{ppm}$ for $-\mathrm{CH}_{2} \mathrm{~N}_{3}$ protons in the ${ }^{1} \mathrm{H}-\mathrm{NMR}$ and $2094 \mathrm{~cm}^{-1}$ for $-\mathrm{N}_{3}$ groups in the FT-IR spectrum of PECH-N $\mathrm{N}_{3}$ were further evidences that $\mathrm{PECH}-\mathrm{N}_{3}$ was successfully obtained.

\subsection{Synthesis of PMMA-propargyl by redox polymerization}

PMMA-propargyl was synthesized at $30^{\circ} \mathrm{C}$ by redox polymerization [33]. Scheme 1 (second line) includes the reaction pathway for the synthesis of PMMA-propargyl. The formation of the specific acetylenic $\mathrm{C}-\mathrm{H}$ stretching band at about $3350 \mathrm{~cm}^{-1}$ proves the propargylation of PMMA. Furthermore, the observed peak at $1.1 \mathrm{ppm}$ for $-\mathrm{C} \equiv \mathrm{CH}$ protons was the other evidence that PMMA-propargyl was obtained.
Scheme 1. Reaction pathways in the synthesis of PECH-N and PMMA-propargyl
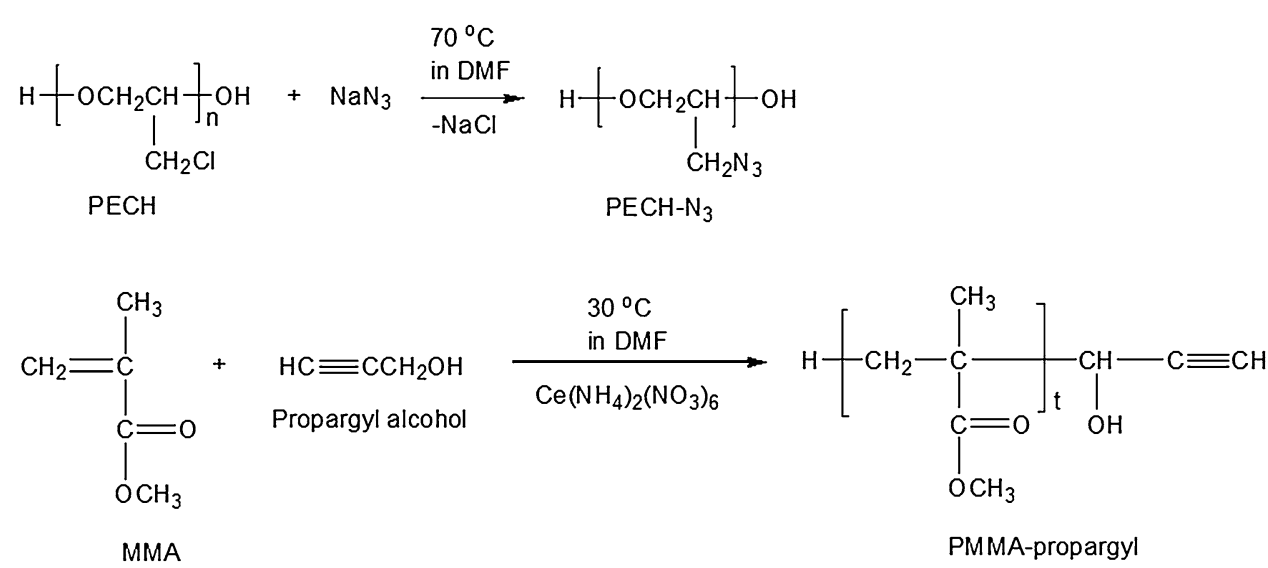


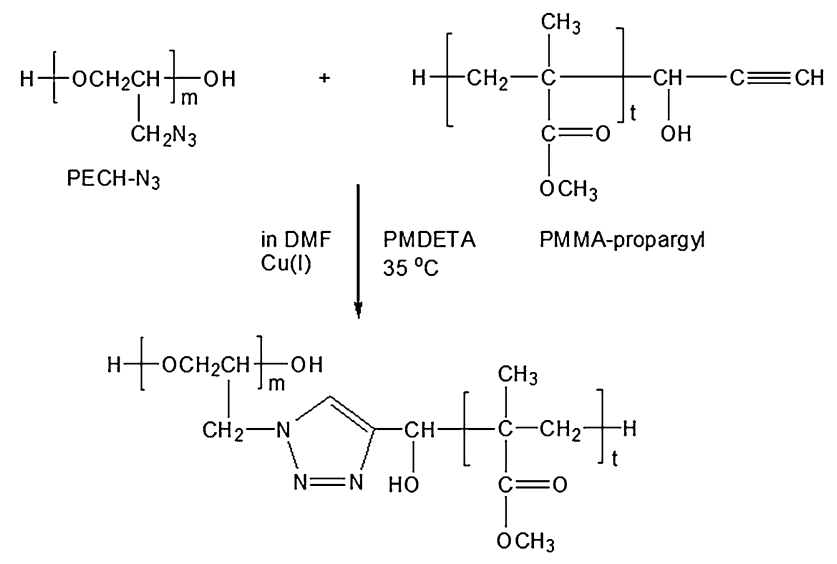

Poly(ECH-g-MMA) graft copoymer

Scheme 2. Reaction outline for synthesis of poly(ECH-g-MMA) comb-type graft copolymer

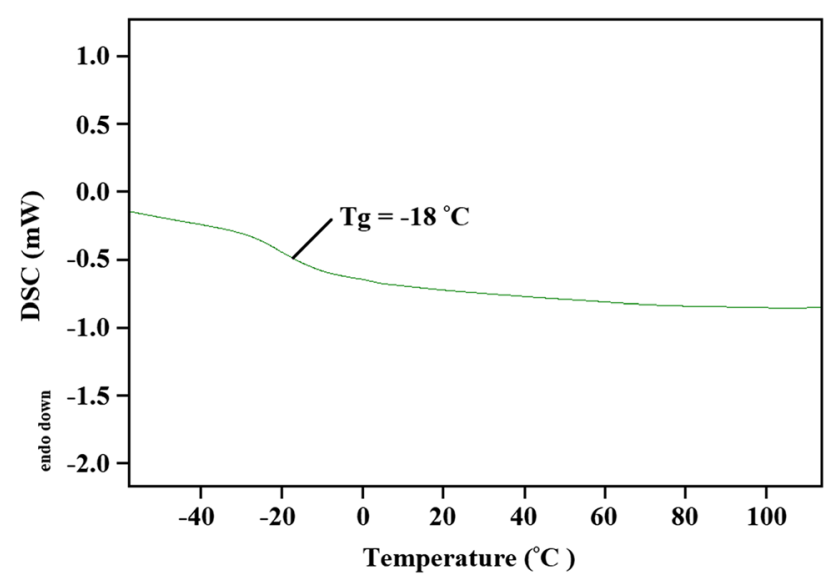

Fig. 3 DSC curve of poly(ECH-g-MMA) comb-type graft copolymer (R2M2-2 in Table 1)

\subsection{Synthesis of poly(ECH-G-MMA) comb-type graft copolymers by "click" chemistry}

Poly(ECH-g-MMA) comb-type graft copolymers were synthesized at $35^{\circ} \mathrm{C}$ via the "click" chemistry of $\mathrm{PECH}-\mathrm{N}_{3}$ and PMMA-propargyl. Scheme 2 shows the reaction outline for synthesis of the comb-type graft copolymer. The signal at about $8.0 \mathrm{ppm}$ in the ${ }^{1} \mathrm{H}-\mathrm{NMR}$ spectrum is an indisputable evidence of aromatic - $\mathrm{CH}$ proton of triazole $[34,35]$.

Thermal analysis of poly(ECH-g-EG) comb-type graft copolymers was carried out by DSC and TGA. Tg value of the comb-type graft copolymer (R2M2-2 in Table 1) was $-18^{\circ} \mathrm{C}$ (Fig. 3). Tg values were reported in the literatures for homo PECH and homo PMMA as $-43^{\circ} \mathrm{C}[36]$ and $105^{\circ} \mathrm{C}$ [37], respectively. $\mathrm{Tg}$ value of the comb-type graft copolymer changed to the value which was less than the value of

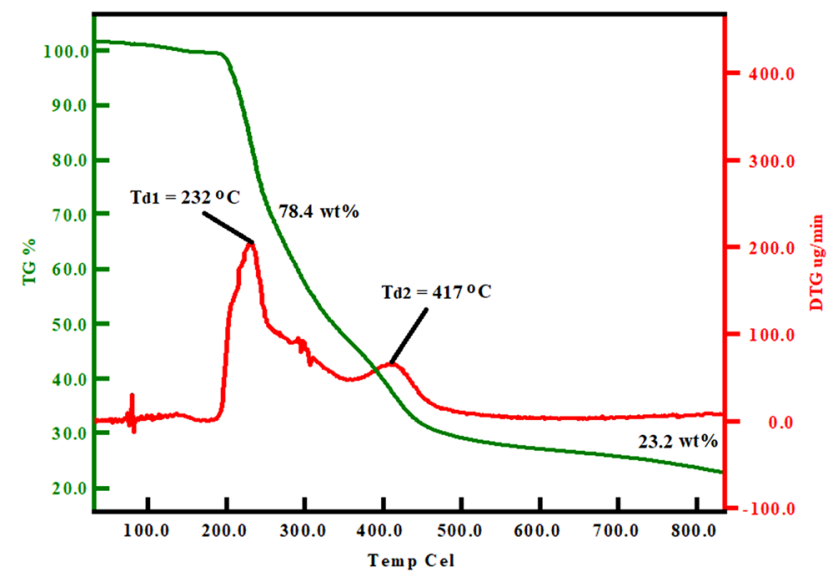

Fig. 4 TGA curves of poly(ECH-g-MMA) comb-type graft copolymer (R2M2-4 in Table 1)

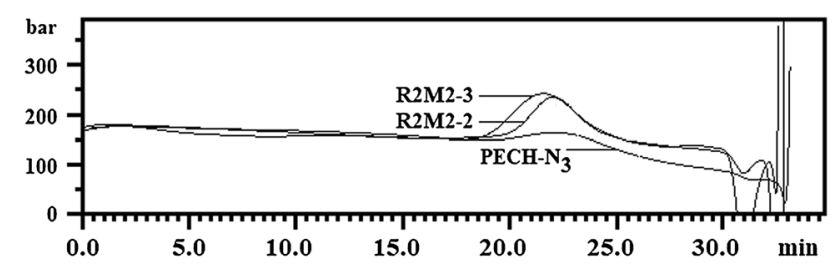

Fig. 5 GPC curves of poly(ECH-g-MMA) comb-type graft copolymers (R2M2-2 and R2M2-3 in Table 1) and PECH-N 3

PMMA because of PECH segment. The only one glass transition temperature value for the comb-type graft copolymers shows the miscible nature of the related polymers. Decomposition temperatures (Td) of the comb-type graft copolymers obtained from TGA were shown in Table 1. In the case of poly(ECH-g-MMA) comb-type graft copolymer, PECH and PMMA units have the individual Td as shown in Fig. 4. As reported for many copolymers [38-41], moieties in a copolymer exhibit decomposition curves as if they are alone. TGA has showed interesting properties of the copolymers indicating continuous weight loss starting from $180^{\circ} \mathrm{C}$ to nearly $510^{\circ} \mathrm{C}$ with derivatives at $232^{\circ} \mathrm{C}$ and $417^{\circ} \mathrm{C}$ through two steps (Fig. 4). Figure 5 indicates the unimodal GPC curves of the comb-type graft copolymers. $\mathrm{Mn}$ values of the comb-type graft copolymers were between $39,128 \mathrm{~g} \mathrm{~mol}^{-1}$ and 25,717 $\mathrm{g} \mathrm{mol}^{-1}$. Dispersity values of the copolymers are between 2.10 and 1.97. Increases in the molecular weights of the copolymers as compared with these of reactants is consistent with the formation of the comb-type graft copolymer.

SEM images of the copolymers were taken for the surface morphology characterization of the copolymers. The polymers were coated with a thin layer of gold on their surfaces. The images were received from different views. The surface morphologies of poly (ECH-g-MMA) comb-type 


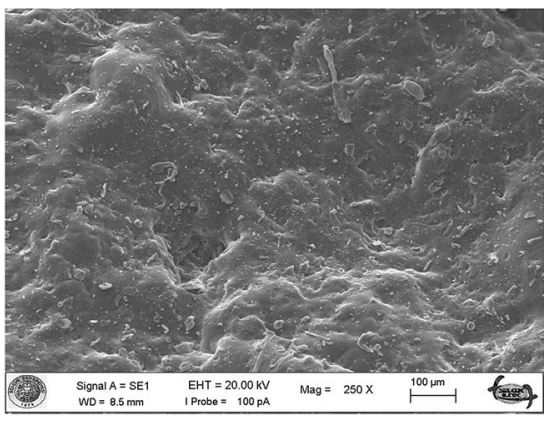

(A)

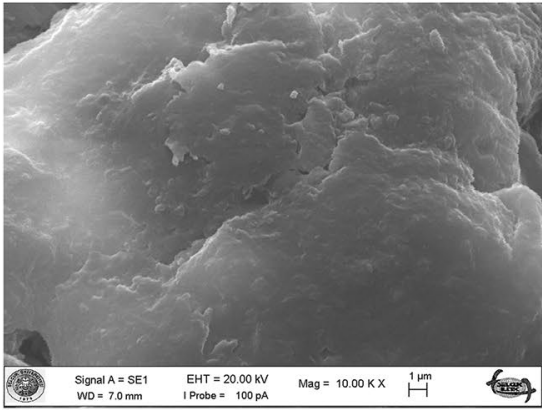

(D)

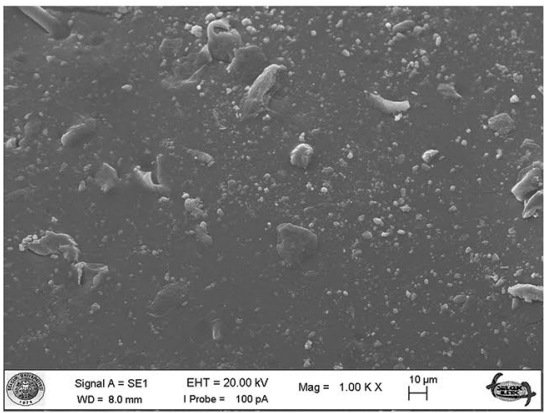

(G)

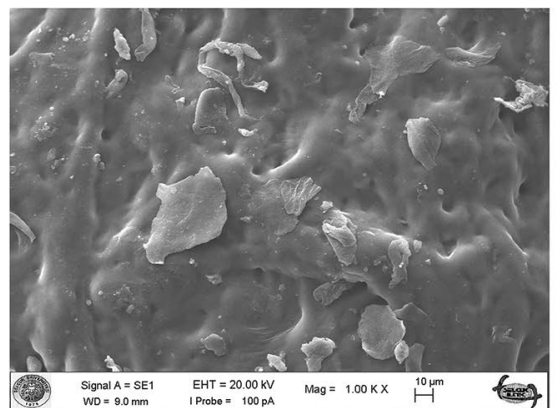

(B)

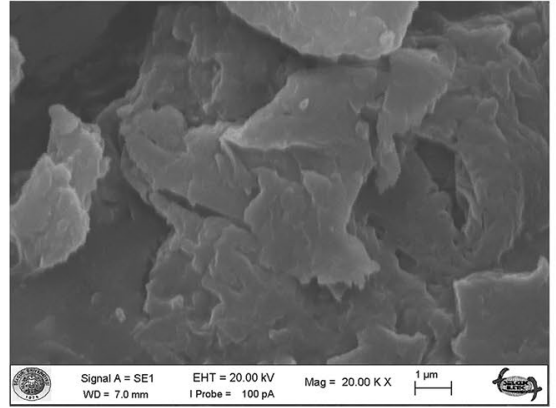

(E)

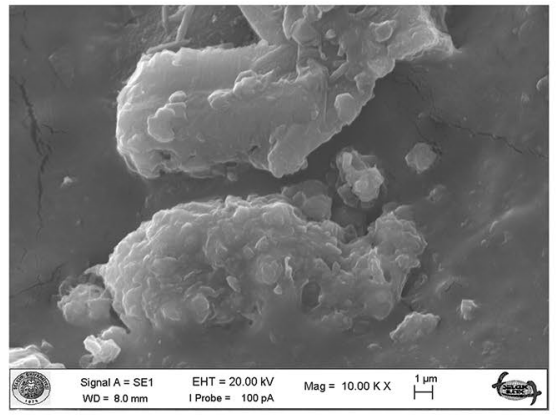

(H)

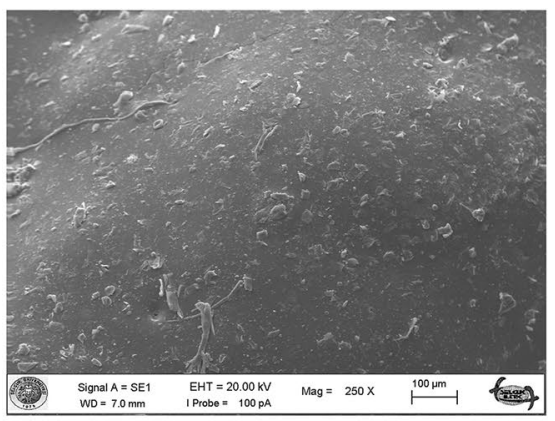

(C)

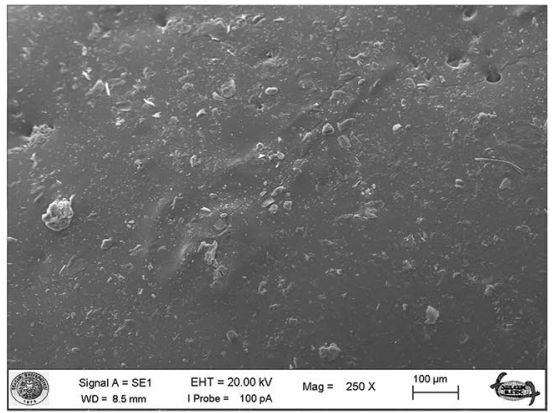

(F)

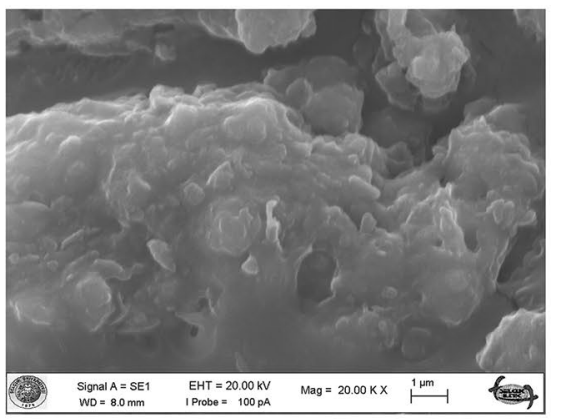

(I)

Fig. 6 SEM images of poly(ECH-g-MMA) comb-type graft copolymer; $\times 250$ (a), and $\times 1000$ (b) (R2M2-1 in Table 1); $\times 250$ (c), $\times 10,000$ (d), and $\times 20,000(\mathbf{e})(\mathrm{R} 2 \mathrm{M} 2-2$ in Table 1); $\times 250(\mathbf{f}), \times 1000(\mathbf{g}), \times 10,000(\mathbf{h})$, and $\times 20,000$ (i) (R2M2-3 in Table 1)

graft copolymers was shown in Fig. 6 (R2M2-1, R2M2-2, and R2M2-3 in Table 1). According to the SEM images of poly(ECH-g-MMA) comb-type graft copolymers, homogenization of the copolymers was good. The copolymer samples were characterized by a morphology consisting platelets with channels. The SEM images of the comb-type graft copolymers show a rough surface and form a continuous phase.

\section{Conclusions}

The "click" chemistry synthesis of the comb-type graft copolymers from the two constituent homopolymers was acquired. This method for synthesis of the comb-type graft copolymers including triazole rings is simple and efficient. Products characterization was done using multi instruments. This study can provide wellcharacterized materials with wide biomedical application potential through the polymers including $\mathrm{PECH}$ and PMMA units.

Acknowledgements The work was founded by Kafkas University Scientific Research Fund (Grand Number: 2018-FM-77).

\section{Compliance with Ethical Standards}

Conflict of interest On behalf of all authors, the corresponding author states that there is no conflict of interest. The authors declare that we have no conflict of interest.

\section{SN Applied Sciences}




\section{References}

1. Kolb HC, Finn MG, Sharpless KB (2001) Click chemistry: diverse chemical function from a few good reactions. Angew Chem Int Edit 40:2004-2021. https://doi.org/10.1002/1521-3773(20010 601)40:11\%3c2004:AID-ANIE2004\%3e3.0.CO;2-5

2. Öztürk T, Meyvacı E, Bektaş H, Menteşe E (2019) Synthesis and characterization of ring-type and branched polymers including polyethylene glycols by "click" chemistry. SN Appl Sci 1:343. https://doi.org/10.1007/s42452-019-0360-4

3. Moses JE, Moorhouse AD (2007) The growing applications of click chemistry. Chem Soc Rev 36:1249-1262. https://doi. org/10.1039/B613014N

4. Hein CD, Liu XM, Wang D (2008) Click chemistry, a powerful tool for pharmaceutical sciences. Pharm Res 25:2216-2230. https://doi.org/10.1007/s11095-008-9616-1

5. Balasubramanian R, Kumutha K, Sarojadevi M (2016) Mechanical, thermal and electrical properties of polyimides containing 1, 2, 3-triazole ring prepared by click reaction. Polym Bull 73:309-330. https://doi.org/10.1007/s00289-015-1488-z

6. Albadi J, Shiran JA, Mansournezhad A (2014) Click synthesis of 1,4-disubstituted-1,2,3-triazoles catalysed by $\mathrm{CuO}-\mathrm{CeO}_{2}$ nanocomposite in the presence of amberlite-supported azide. J Chem Sci 126:147-150. https://doi.org/10.1007/s1203 9-013-0537-0

7. Tunca U (2013) Triple click reaction strategy for macromolecular diversity. Macromol Rapid Commun 34:38-46. https://doi. org/10.1002/marc.201200656

8. Altıntas O, Tunca U (2011) Synthesis of terpolymers by click reactions. Chem Asian J 6:2584-2591. https://doi.org/10.1002/ asia. 201100138

9. Şanal T, Koçak I, Hazer B (2017) Synthesis of comb-type amphiphilic graft copolymers derived from chlorinated poly $(\varepsilon-$ caprolactone) via click reaction. Polym Bull 74:977-995. https ://doi.org/10.1007/s00289-016-1757-5

10. Andrianov AM, Nikolaev GI, Kornoushenko YV, Usanov SA (2019) Click chemistry in silico, docking, quantum chemical calculations, and molecular dynamics simulations to identify novel 1,2,4-triazole-based compounds as potential aromatase inhibitors. SN Appl Sci 1:1026. https://doi.org/10.1007/s4245 2-019-1051-X

11. Xi W, Scott TF, Kloxin CJ, Bowman CN (2014) Click chemistry in materials science. Adv Funct Mater 24:2572-2590. https:// doi.org/10.1002/adfm.201302847

12. Öztürk T, Meyvacı E (2017) Synthesis and characterization poly( $\varepsilon$-caprolactone-b-ethylene glycol-b-e-caprolactone) ABA type block copolymers via "click" chemistry and ring-opening polymerization. J Macromol Sci Part A Pure Appl Chem 54:575-581. https://doi.org/10.1080/10601325.2017.1309251

13. Glaied O, Delaite C, Riess G (2012) Synthesis of PCL-b-PVAc block copolymers by combination of click chemistry, ROP, and RAFT polymerizations. Polym Bull 68:607-621. https:// doi.org/10.1007/s00289-011-0557-1

14. Öztürk T, Cavicchi CA (2018) Synthesis and characterization of poly(epichlorohydrin-g- $\varepsilon$-caprolactone) graft copolymers by click chemistry. J Polym Mater 35:209-220. https://doi. org/10.32381/JPM.2018.35.02.6

15. Binder WH, Sachsenhofer R (2007) 'Click' chemistry in polymer and materials science. Macromol Rapid Comm 28:15-54. https ://doi.org/10.1002/marc.200600625

16. Hoogenboom R, Moore BC, Schubert US (2006) Synthesis of star-shaped poly( $\varepsilon$-caprolactone) via 'click' chemistry and 'supramolecular click' chemistry. Chem Commun 2006:40104012. https://doi.org/10.1039/B608313G
17. Enomoto-Rogers Y, Iwata T (2012) Synthesis of xylan-graftpoly(L-lactide) copolymers via click chemistry and their thermal properties. Carbohydr Polym 87:1933-1940. https://doi. org/10.1016/j.carbpol.2011.09.092

18. Al-Kaabi K, van Reene AJ (2008) Controlled radical polymerization of poly(methyl methacrylate-g-epichlorohydrin) using $\mathrm{N}$,-N-dithiocarbamate-mediated iniferters. J Appl Polym Sci 108:2528-2534. https://doi.org/10.1002/app.27267

19. Cho BS, Noh ST (2013) Synthesis and thermal properties of ferrocene-modified poly(epichlorohydrin-co-2-(methoxymethyl) oxirane). Macromol Res 21:221-227. https://doi.org/10.1007/ s13233-013-1074-x

20. Tang T, Fan $X$, Jin $Y$, Wang G (2014) Synthesis and characterization of graft copolymers with poly(epichlorohydrin-co-ethylene oxide) as backbone by combination of ring-opening polymerization with living anionic polymerization. Polymer 55:3680-3687. https://doi.org/10.1016/j.polymer.2014.05.066

21. Danner AK, Leibig D, Vogt LM, Frey H (2019) Monomer-activated copolymerization of ethylene oxide and epichlorohydrin: In situ kinetics evidences tapered block copolymer formation. Chinese J Polym Sci 37:912-918. https://doi. org/10.1007/s10118-019-2296-y

22. Öztürk T, Atalar MN, Göktaş M, Hazer B (2013) One-step synthesis of block-graft copolymers via simultaneous reversible-addition fragmentation chain transfer and ring-opening polymerization using a novel macroinitiator. J Polym Sci Part A Polym Chem 51:2651-2659. https://doi.org/10.1002/ pola.26654

23. Kwon GS, Kataoka K (2012) Block copolymer micelles as longcirculating drug vehicles. Adv Drug Deliv Rev 64:237-245. https ://doi.org/10.1016/j.addr.2012.09.016

24. Öztürk T, Yavuz M, Göktaş M, Hazer B (2016) One-step synthesis of triarm block copolymers by simultaneous atom transfer radical and ring-opening polymerization. Polym Bull 73:1497-1513. https://doi.org/10.1007/s00289-015-1558-2

25. Ma Y, Zeng J, Zeng Y, Zhou H, Liu G, Liu Y, Zeng L, Jian J, Yuan Z (2020) Preparation and performance of poly(4-vinylpyridine)b-polysulfone-b-poly4-vinylpyridine triblock copolymer/polysulfone blend membrane for separation of palladium (II) from electroplating wastewaters. J Hazard Mater 384:121277. https ://doi.org/10.1016/j.jhazmat.2019.121277

26. Buruiana EC, Chibac AL, Melinte V, Buruiana T (2013) Preparation of amphiphilic block copolymer containing triazene moieties and fluorescence study. J Chem Sci 125:193-202. https://doi. org/10.1007/s12039-012-0350-1

27. Ruzette AV, Leibler $L$ (2005) Block copolymers in tomorrow's plastics. Nat Mater 4:19-31. https://doi.org/10.1038/nmat1295

28. Mijinyawa AH, Durga G, Mishra A (2019) Evaluation of thermal degradation and melt crystallization behavior of taro mucilage and its graft copolymer with polylactide. SN Appl Sci 1:1486. https://doi.org/10.1007/s42452-019-1490-4

29. Riess G (2003) Micellization of block copolymers. Prog Polym Sci 28:1107-1170. https://doi.org/10.1016/S0079-6700(03)00015-7

30. Gacal B, Durmaz H, Tasdelen MA, Hizal G, Tunca U, Yagci Y, Demirel AL (2006) Anthracene-maleimide-based Diels-Alder "click chemistry" as a novel route to graft copolymers. Macromolecules 39:5330-5336. https://doi.org/10.1021/ma060690c

31. Fischer M, Hellmann GP (1996) Block-graft copolymers on the basis of a styrene-butadiene diblock copolymer. Polymer 37:4547-4554. https://doi.org/10.1016/0032-3861(96)00242-X

32. Xie M, Dang J, Han H, Wang W, Liu J, He X, Zhang Y (2008) Welldefined brush copolymers with high grafting density of amphiphilic side chains by combination of ROP, ROMP, and ATRP. Macromolecules 41:9004-9010. https://doi.org/10.1021/ma801408s

33. Savaş B (2015) Synthesis of macro monomers containing triazol ring and graft polymerization (Triazol halkası ihtiva eden 
makromonomerlerin sentezi ve graft kopolimerizasyonu), PhD Thesis, Kafkas University, Kars, Turkey.

34. Lakouraj MM, Hasantabar V, Bagheri N (2013) Synthesis of polyethers containing triazole units in the backbone by click chemistry in a tricomponent reaction. J Polym 2013:167106. https:// doi.org/10.1155/2013/167106

35. Rukmanikrishnan B, Muthusamy S (2018) Preparation and properties of polyimides containing 1,2,3-triazole moieties. Adv Polym Tech 37:21641. https://doi.org/10.1002/adv.21641

36. Ren $Y$, Wu G, Zhao X, Liu X, Liu F (2010) Effect of poly(epichlorohydrin) on the thermal and mechanical properties of poly(vinyl chloride). J Appl Polym Sci 118:3416-3424. https://doi.org/10.1002/app.32687

37. Brandrup J, Immergut EH (1975) Polymer handbook, 2nd edn. Wiley, New York

38. Thanomsilp C, Phetthianchai U (2012) Synthesis and characterization of PLA-CO-PEG copolymers. Adv Mat Res 506:178-181. https://doi.org/10.4028/www.scientific.net/AMR.506.178
39. Çatıker E, Basan S (2017) Miscibility and thermal degradation kinetics of poly- $\beta$ - alanine/poly(3-hydroxypropionate) blends. JOTCSA 4:341-354. https://doi.org/10.18596/jotcsa.65456

40. Çatıker E, Sancaktar E (2014) Blends of poly(3-hydroxybutyrate) with poly( $\beta$-alanine) and its derivatives. J App Polym Sci 131:40484. https://doi.org/10.1002/app.40484

41. Jamshid MR (2008) Synthesis and thermal properties of novel multiblock biodegradable copolymers derived from polyethylene glycol, $\varepsilon$-caprolactone and p-dioxanone. ScienceAsia 34:207-213. https://doi.org/10.2306/scienceasia1513 $-1874.2008 .34 .207$

Publisher's Note Springer Nature remains neutral with regard to jurisdictional claims in published maps and institutional affiliations. 